\title{
HUBUNGAN PENGETAHUAN REMAJA TENTANG HIV/AIDS DENGAN PERILAKU SEKSUAL REMAJA DI SMK MUTIARA KOTA BANDUNG
}

\author{
Ketut Anom Sri Kesumawati \\ Prodi D III Kebidanan, Universitas Triatma Mulya, Bali, Indonesia \\ Email corresponding: kesumawati08@gmail.com \\ (Diterima 25-10-2019; disetujui 18-11-2019; dipublish 27-11-2019)
}

\begin{abstract}
Abstrak
Survei Kesehatan Reproduksi Remaja Indonesia (SKRRI) di tahun 2002-2003, remaja mengatakan mempunyai teman yang pernah melakukan hubungan seksual pada usia 14-19 tahun, perempuan $34,7 \%$, laki-laki 30,9\%. Sedangkan pada usia 20-24 tahun perempuan 48,6\% dan laki-laki 46,5\%. Pengetahuan remaja tentang HIV/AIDS merupakan salah satu komponen faktor predisposisi yang penting walaupun dengan peningkatkan pengetahuan tidak akan selalu menyebabkan terjadinya perubahan perilaku tetapi mempunyai hubungan yang positif. Populasi dalam penelitian ini adalah seluruh siswa siswi yang berusia 15-16 tahun di SMK Mutiara Bandung tahun 2014 yang berjumlah 142 orang. Sampel dalam penelitian ini adalah siswa siswi kelas X-XI yang berusia 15-16 tahun di SMK Mutiara Bandung tahun 2014. Tehnik pengambilan sampel yang akan digunakan pada penelitian ini adalah metode sample random sampling. Berdasarkan hasil penelitian dapat diketahui bahwa dari 39 responden, yang berpengetahuan kurang dengan perilaku seksual tidak baik sebanyak 27 responden (69.2\%). Perilaku seksual responden yang kurang dipengaruhi oleh faktor pengaruh teman sebaya, dan lingkungannya. Sedangkan responden berpengetahuan kurang dengan perilaku baik sebanyak 12 responden $(30.8 \%)$.

Kata Kunci : Pengetahuan, HIV/AIDS, Perilaku Seksual
\end{abstract}

\begin{abstract}
Indonesian Youth Reproductive Health Survey (SKRRI) in 2002-2003, adolescents said they had friends who had had sexual relations at the age of 14-19 years, women 34.7\%, men 30.9\%. Whereas at the age of 20-24 years women are 48.6\% and men are 46.5\%. Adolescent knowledge about HIV / AIDS is one important component of predisposing factors although increasing knowledge will not always lead to behavior change but has a positive relationship. The population in this study were all students aged 15-16 years at SMK Mutiara Bandung in 2014, amounting to 142 people. The sample in this study were students of class X-XI aged 15-16 years at SMK Mutiara Bandung in 2014. The sampling technique that will be used in this study is the sample random sampling method. Based on the results of the study it can be seen that of the 39 respondents, who lack knowledge with bad sexual behavior as many as 27 respondents (69.2\%). Sexual behavior of respondents who are less influenced by factors influencing peers, and their environment. Whereas respondents who lack knowledge with good behavior are 12 respondents (30.8\%).
\end{abstract}

Keywords: Knowledge, HIV / AIDS, Sexual Behavior 


\section{PENDAHULUAN}

Dari hasil estimasi Kemenkes RI tahun 2013 menunjukkan bahwa jumlah penduduk Indonesia sebesar 248.422.956 jiwa, 71.708.907 jiwa diantaranya adalah remaja yang terdiri dari laki-laki sebanyak 36.890 .004 jiwa $(51,5 \%)$ dan perempuan sebanyak 34.818.903 jiwa $(48,5 \%)^{1}$. Jumlah remaja yang tidak sedikit ini memberikan potensi yang sangat berarti dalam melanjutkan pembangunan di Indonesia. Berbagai upaya dalam menggali potensi ini tertulis dalam Garis-garis Besar Haluan Negara (GBHN) bahwa pembinaan anak dan remaja dilaksanakan melalui peningkatan mutu gizi, pembinaan perilaku kehidupan beragama dan budi pekerti luhur, penumbuhan minat belajar, peningkatan daya cipta, daya nalar serta kreativitas, penumbuhan kesadaran untuk hidup sehat, serta penumbuhan idealisme dan patriotisme. Semua hal-hal tersebut dibentuk dalam pengamalan pancasila dan peningkatan kemampuan remaja dalam menyesuaikan diri dengan lingkungan dan masyarakat. Dalam upaya pembangunan tersebut terjadi ketidakseimbangan yang memberikan pengaruh yang besar pada remaja sehingga memberikan tambahan beban pada pembangunan itu sendiri ${ }^{2,3}$.

Salah satu dampak dari ketidakseimbangan tersebut mengakibatkan terjadinya perubahan yang mendasar dalam sikap dan perilaku seksual pra nikah di kalangan remaja. Beberapa kasus dan hasil penelitian menunjukkan terjadinya pergeseran nilainilai sikap dan perilaku tersebut.

Di tahun 2005 Yayasan DKT melakukan penelitian yang sama yang memfokuskan penelitian di daerah Jabodetabek, Bandung, Surabaya dan Medan. Memperoleh hasil $89 \%$ remaja tidak setuju dengan adanya seks pra nikah. Namun kenyataannya fenomena yang terjadi di lapangan, $82 \%$ remaja punya teman yang melakukan seks pra nikah, $62 \%$ remaja punya teman yang hamil sebelum menikah, dan remaja-remaja yang secara terbuka menyatakan melakukan seks pra nikah di Jabodetabek 51\%, Bandung 54\%, Surabaya 47\% dan Medan 52\%. Tahun 2006 PKBI kembali melakukan penelitian dan memperoleh hasil bahwa remaja usia 13-18 tahun telah melakukan hubungan seks dengan $60 \%$ tidak menggunakan alat kontrasepsi dan sisanya $85 \%$ remaja tersebut melakukan hubungan seks di rumah sendiri 4.

Permasalahan lain yang juga muncul dikalangan remaja yang dihadapi saat ini seperti rendahnya pengetahuan remaja tentang kesehatan reproduksi, khususnya dalam melindungi diri dari perilaku seksual yang beresiko, pencegahan kehamilan yang tidak diinginkan serta masih banyaknya remaja yang mengganggap HIV/AIDS sebagai penyakit yang tak berbahaya serta masih banyak lagi pemahaman yang keliru terkait penyakit tersebut ${ }^{5}$.

Pengetahuan remaja tentang HIV/AIDS merupakan salah satu komponen faktor predisposisi yang penting walaupun dengan peningkatkan pengetahuan tidak akan selalu menyebabkan terjadinya perubahan perilaku tetapi mempunyai hubungan yang positif. Menurut hasil penelitian yang dilakukan oleh Cindra (2013) yang dilakukan di SMA Negeri 1 Gorontalo menunjukkan adanya hubungan yang signifikan antara pengetahuan tentang HIV/AIDS dengan perilaku seksual siswa kelas XI di SMA Negeri 1 Gorontalo.

Pengetahuan mengenai kesehatan reproduksi saat ini dapat diperoleh dari berbagai media, seperti koran, majalah, radio, televisi, dan internet selain itu mereka juga dapat memperoleh pengetahuan melalui dunia pendidikan. Sekolah menengah kejuruan merupakan jenjang pendidikan setelah lulus dari sekolah menengah pertama. Sekolah menengah kejuruan merupakan gerbang 
awal memasuki masa remaja, dimana anak mencari jati dirinya. Masa ini dapat dikatakan masa yang berbahaya dimana anak mencoba-coba hal-hal baru sehingga anak sulit untuk dikontrol dan perlu pengawasan dari orang tua.

\section{METODE PENELITIAN}

Jenis penelitian yang akan dilakukan pada penelitian ini menggunakan pendekatan survei analitik yaitu penelitian yang menggali bagaimana dan mengapa suatu fenomena kesehatan dapat terjadi serta mengetahui seberapa jauh kontribusi faktor risiko tertentu terhadap adanya suatu keadaan $\left(\right.$ efek) ${ }^{6}$.

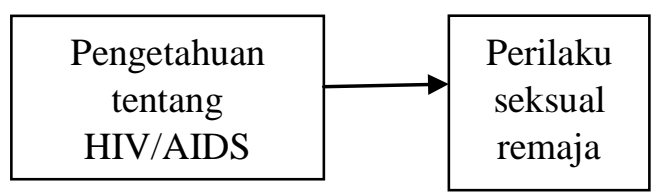

Gambar 1 Kerangka Konsep Penelitian

Variabel bebas dalam penelitian ini adalah pengetahuan remaja tentang HIV/AIDS. Variabel terikat dalam penelitian ini adalah perilaku seksual remaja usia 15-16 tahun yang diperoleh melalui kuesioner yang diisi secara pribadi oleh responden. Populasi dalam penelitian ini adalah seluruh siswa siswi yang berusia 15-16 tahun di SMK Mutiara Bandung tahun 2014 yang berjumlah 142 orang. Sampel dalam penelitian ini adalah siswa siswi kelas X-XI yang berusia 15-16 tahun di SMK Mutiara Bandung tahun 2014. Tehnik pengambilan sampel yang akan digunakan pada penelitian ini adalah metode sample random sampling ${ }^{7}$.

\section{HASIL PENELITIAN \\ Analisis Univariat}

Gambaran Pengetahuan Remaja Tentang HIV/AIDS di SMK Mutiara Kota Bandung Tahun 2014. Berdasarkan hasil penelitian diperoleh gambaran pengetahuan remaja tentang HIV/AIDS di SMK Mutiara Kota Bandung Tahun 2014 sebagai berikut:

Tabel 1 Distribusi $\quad$ Frekuensi Pengetahuan Remaja Tentang HIV/AIDS dengan Perilaku Seksual Remaja di SMK Mutiara Kota Bandung Tahun 2014

\begin{tabular}{lll}
\hline $\begin{array}{l}\text { Pengetahuan } \\
\text { Remaja Tentang } \\
\text { HIV/AIDS }\end{array}$ & (n) & $\begin{array}{l}\text { Persentase } \\
(\%)\end{array}$ \\
\hline Kurang & 39 & 39.0 \\
\hline Cukup & 47 & 47.0 \\
\hline Baik & 19 & 19.0 \\
\hline Total & 105 & 100 \\
\hline
\end{tabular}

Berdasarkan tabel 4.1 dapat diketahui bahwa dari 105 responden sebagian besar responden yang memiliki pengetahuan cukup sebanyak 47 responden $(47.0 \%)$, dan 39 responden $(39.0 \%)$ memiliki pengetahuan kurang tentang HIV/AIDS.

Gambaran Perilaku Seksual Remaja di SMK Mutiara Kota Bandung Tahun 2014 Berdasarkan hasil penelitian diperoleh gambaran perilaku seksual remaja di SMK Mutiara Kota Bandung sebagai berikut:

Tabel 4.2 Distribusi Frekuensi Perilaku Seksual Remaja di SMK Mutiara Kota Bandung Tahun 2014.

\begin{tabular}{lll}
\hline $\begin{array}{l}\text { Perilaku } \\
\begin{array}{l}\text { Seksual } \\
\text { Remaja }\end{array}\end{array}$ & $\begin{array}{l}\text { Frekuensi } \\
(\mathrm{n})\end{array}$ & $\begin{array}{l}\text { Persentase } \\
(\%)\end{array}$ \\
\hline Tidak baik & 48 & 45.7 \\
\hline Baik & 57 & 54.3 \\
\hline Total & 105 & 100 \\
\hline
\end{tabular}

Berdasarkan tabel 4.2 dapat diketahui bahwa dari 105 responden sebagian besar responden memiliki perilaku seksual baik sebanyak 57 responden (54.3\%), dan 48 responden $(45.7 \%)$ memiliki perilaku seksual tidak baik

\section{Analisis Bivariat}


Analisis dilakukan untuk melihat hubungan antara pengetahuan remaja tentang HIV/AIDS (variabel independen). Adapun sebagai variabel dependen yaitu perilaku seksual remaja usia 15-16 tahun di SMK Mutiara Kota Bandung tahun 2014. Uji statistik yang digunakan pada penelitian ini adalah analisis Chi-Square.

\section{Analisis Hubungan Antara Pengetahuan Remaja Tentang HIV/AIDS dengan Perilaku Seksual Remaja di SMK Mutiara Kota Bandung Tahun 2014}

Berdasarkan hasil penelitian diperoleh hasil analisis hubungan pengetahuan remaja tentang HIV/AIDS dengan perilaku seksual remaja di SMK Mutiara Kota Bandung sebagai berikut:

Tabel 4.3 Analisis Hubungan Antara Pengetahuan Remaja Tentang HIV/AIDS dengan Perilaku Seksual Remaja di SMK Mutiara Kota Bandung Tahun 2014

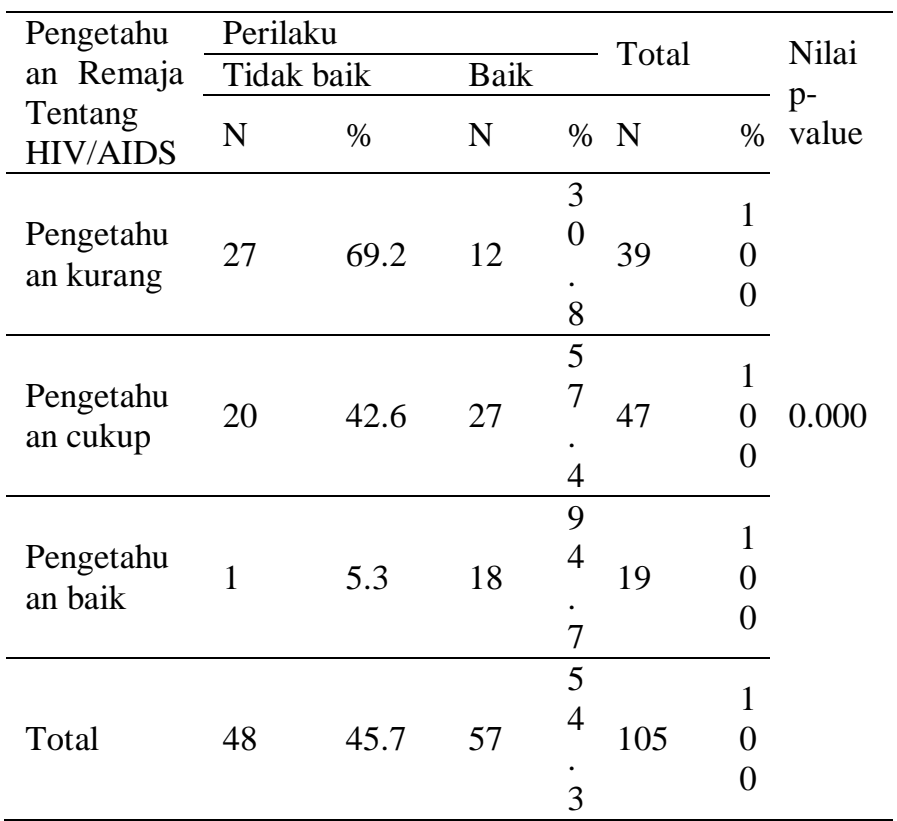

Berdasarkan tabel 4.3 dapat diketahui bahwa dari 39 responden, yang berpengetahuan kurang dengan perilaku seksual tidak baik sebanyak 27 responden (69.2\%). Dari 47 responden yang berpengetahuan cukup dengan perilaku seksual baik sebanyak 27 responden (57.4\%). Sedangkan dari 19 responden yang berpengetahuan baik dengan perilaku seksual baik sebanyak 18 responden (94.7\%). Dengan $\mathrm{p}=0.000$ memiliki arti bahwa terdapat hubungan antara pengetahuan remaja tentang HIV/AIDS dengan perilaku seksual remaja. Hasil analisis hubungan antara pengetahuan remaja tentang HIV/AIDS dengan perilaku seksual remaja di SMK Mutiara Kota Bandung dari 105 responden sebagian besar responden memiliki pengetahuan kurang dengan perilaku seksual tidak baik sebanyak 27 responden $(69.2 \%)$ dan perilaku baik sebanyak 12 responden $(30.8 \%)$. Responden yang memiliki pengetahuan cukup dengan perilaku seksual baik sebanyak 27 responden $(57.4 \%)$ dan perilaku seksual tidak baik 20 responden (42.6\%). Sebagian kecil responden memiliki pengetahuan baik dengan perilaku seksual baik sebanyak 18 responden $(94.7 \%)$ dan 1 responden $(5.3 \%)$ memiliki perilaku seksual tidak baik. Hubungan antara pengetahuan remaja tentang HIV/AIDS dengan perilaku seksual remaja memiliki $\mathrm{p}=0.000$.

Berdasarkan hasil penelitian dapat diketahui bahwa dari 39 responden, yang berpengetahuan kurang dengan perilaku seksual tidak baik sebanyak 27 responden (69.2\%). Perilaku seksual responden yang kurang dipengaruhi oleh faktor pengaruh teman sebaya, dan lingkungannya. Sedangkan responden berpengetahuan kurang dengan perilaku baik sebanyak 12 responden $(30.8 \%)$. Hal ini dapat terjadi karena faktor informasi yang diterima responden baik dari penyuluhan-penyuluhan tentang HIV/AIDS dan peran guru BK (Bimbingan Konseling).Responden yang berpengetahuan cukup dengan perilaku baik sebanyak 27 responden (57.4\%). Hal ini disebabkan oleh faktor hubungan dengan orang tua yang kurang harmonis dan pengaruh teman sebaya. Sedangkan hal yang sebaliknya terjadi pada responden yang 
berpengetahuan cukup dengan perilaku baik sebanyak 20 responden $(42.6 \%)$. Hal yang berbeda terjadi pada 47 responden berpengetahuan baik dengan perilaku baik sebanyak 18 responden (94.7\%). Namun terdapat 1 responden $(5.3 \%)$ yang berpengetahuan baik dengan perilaku tidak baik. Hal ini dapat dipengaruhi oleh faktor pergaulan dan lingkungan baik dari orang tua maupun tekanan negatif dari teman sebaya sehingga mudah dipengaruhi untuk melakukan perilaku seksual pranikah.

Pengetahuan merupakan hasil tahu dan terjadi setelah orang mengadakan penginderaan terhadap suatu objek tertentu. Pegetahuan remaja tentang HIV/AIDS merupakan salah satu komponen faktor predisposisi yang penting dalam mencegah penularan HIV/AIDS pada remaja melalui hubungan seksual baik heteroseksual, homoseksual maupun biseksual . Perilaku seks pada remaja timbul dari hasrat seksual terhadap lawan jenis maupun sesama jenis. Wujud dari tingkah laku tersebut seperti berkencan, bercumbu dan bersenggama ${ }^{8}$.

Penelitian yang dilakukan Cindra yang dilakukan di SMA Negeri 1 Gorontalo menunjukkan adanya hubungan yang signifikan antara pengetahuan tentang HIV/AIDS dengan perilaku seksual siswa kelas XI di SMA Negeri 1 Gorontalo. Sedangkan penelitian yang dilakukan Pratiwi dan Basuki ${ }^{11}$, menunjukkan bahwa usia 15-17 tahun dan remaja usia 22-14 tahun pengetahuan tentang HIV/AIDS lebih rendah dibandingkan usia 18-24 tahun. Hal ini dipengaruhi oleh faktor lingkungan yang memiliki peran yang tidak kalah pentingnya dengan faktor pendorong perilaku seksual pra nikah lainnya. Faktor lingkungan ini bervariasi, ada teman sepermainan (peergroup), pengaruh media dan televisi, bahkan faktor orang tua sendiri.

Dari hasil analisis hubungan antara pengetahuan remaja tentang HIV/AIDS dengan perilaku seksual remaja didapatkan nilai $\mathrm{p}=0.000$ yang artinya terdapat hubungan yang berarti antara pengetahuan remaja tentang HIV/AIDS dengan perilaku seksual remaja. Hal ini sesuai dengan teori bahwa peningkatkan pengetahuan tidak selalu menyebabkan terjadinya perubahan perilaku tetapi mempunyai hubungan yang positif.

\section{SIMPULAN}

Berdasarkan hasil penelitian yang dilakukan pada bulan Juni sampai dengan bulan Agustus 2015 dengan jumlah responden sebanyak 105 orang, maka peneliti dapat mengambil keputusan sebagai berikut:

1. Gambaran pengetahuan remaja tentang HIV/AIDS di SMK Mutiara kota Bandung sebagian besar berpengetahuan cukup sebanyak 47 orang (47\%) dan sebagian kecil berpengetahuan baik sebanyak 19 orang (19\%).

2. Gambaran perilaku seksual remaja yang berperilaku tidak baik 48 orang $(45,7 \%)$ dan berperilaku baik 57 orang $(54.3 \%)$.

3. Terdapat hubungan yang signifikan antara pengetahuan remaja tentang HIV/AIDS dengan perilaku seksual remaja di SMK Mutiara kota Bandung tahun 2014 dengan p-value 0,000 ( $\dot{\alpha} \leq$ $0,05)$.

\section{DAFTAR PUSTAKA}

1. Arikunto, Suharsimi. (2013). Prosedur Penelitian Suatu Pendekatan Praktik. Jakarta: Rineka Cipta

2. BKKBN. (2014). BKKBN Gandeng Raper Ajak Remaja Indonesia Untuk Tidak Nikah Terlalu Dini, Jauhi Narkoba, HIV/AIDS, dan Seks Bebas.

3. Budiman. (2013). Penelitian Kesehatan. Yogyakarta: Pustaka Rihama

4. Cindra. (2013). Hubungan Pengetahuan Tentang HIV/AIDS Dengan Perilaku Seksual Siswa Kelas XI di SMA Negeri 1 Gorontalo. 
5. Faisalado \& Cecep. (2013). Trend Disease Trand Penyakit Saat Ini. Jakarta: Trans info media.

6. Hidayat, A. (2007). Metode Penelitian Kebidanan dan Tehnik Analisa Data. Jakarta: Salemba Medika

7. Irianti dan Herlina.(2011). Buku Ajar Psikologi Untuk Mahasiswa Kebidanan. Jakarta: EGC.

8. Kementerian Kesehatan Republik Indonesia. (2013). Modul Pelatihan Pencegahan Penularan HIV dari Ibu ke Anak (PPIA) Bagi Petugas Kesehatan.Jakarta

9. Kusmiran, Eny. (2014). Kesehatan Reproduksi Remaja dan Wanita. Jakarta: Salemba Medika.

10. Mubarak, Wahit Iqbal. (2011). Promosi Kesehatan Untuk Kebidanan.Jakarta: Salemba Medika

11. Munir, Misbahol, (2010). Tiap Tahun Remaja Seks Pra Nikah Meningkat. 2015. 